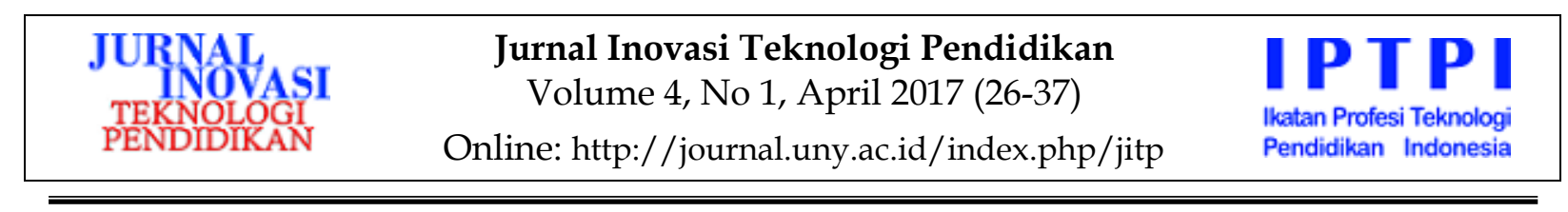

\title{
PENGEMBANGAN ADAPTIVE MOBILE LEARNING PADA MATA PELAJARAN BIOLOGI SMA SEBAGAI UPAYA MENDUKUNG PROSES BLENDED LEARNING
}

\author{
Ence Surahman, Herman Dwi Surjono \\ FIP Universitas Pendidikan Indonesia, FT Universitas Negeri Yogyakarta \\ ence@miti.or.id, hermansurjono@uny.ac.id
}

\begin{abstract}
Abstrak
Penelitian ini bertujuan untuk: (1) menghasilkan produk Adaptive Mobile Learning yang layak menurut ahli materi, ahli media dan pengguna, (2) mengetahui kebermanfaatan produk melalui ketuntasan hasil belajar peserta didik, dan kemampuan program untuk mendukung blended learning. Penelitian pengembangan ini mengikuti langkah-langkah yang dikembangkan oleh Alessi dan Trollip yang terdiri dari tiga tahap, yakni perencanaan, perancangan, dan pengembangan. Produk awal divalidasi oleh ahli media dan ahli materi kemudian dilakukan revisi. Tahap berikutnya dilakukan tes beta 1 terhadap beberapa calon pengguna, dan diujicobakan kepada 29 pengguna. Selanjutnya tes sumatif terhadap 29 peserta didik. Hasil penelitian menunjukkan bahwa: (1) produk Adaptive Mobile Learning dinyatakan layak sebagai media pembelajaran berdasarkan validasi ahli materi, ahli media, dan pengguna dengan rerata kelayakan mencapai skor 3,35 dengan kategori "sangat baik"; (2) kebermanfaatan produk dibuktikan melalui perbedaan hasil belajar mencapai angka kenaikan sebesar 33,80 sesudah menggunakan produk Adaptive Mobile Learning dan terbukti mendukung blended learning dengan skor 3,42 dengan kategori "sangat baik".
\end{abstract}

Kata kunci: adaptive learning, mobile learning, blended learning.

\section{THE DEVELOPING OF ADAPTIVE MOBILE LEARNING IN SENIOR HIGH SCHOOL BIOLOGY SUBJECT AS EFFORTS TO SUPPORT THE PROCESS OF BLENDED LEARNING}

\author{
Ence Surahman, Herman Dwi Surjono \\ FIP Universitas Pendidikan Indonesia, FT Universitas Negeri Yogyakarta \\ ence@miti.or.id, hermansurjono@uny.ac.id
}

\begin{abstract}
This research study aims: (1) producing Adaptive Mobile Learning which fulfil the criteria and appropriateness according to the experts, media experts, and users; and (2) the usefulness of the product seen from the completeness of the student learning outcomes and ability the product to support blended learning process. This research and development study refers to the stages developed by Alessi and Trollip which classified into three stages namely planning, designing, and developing. Early product was validated by the media and experts (alpha test), followed by revision. The next stage namely beta 1 test was done by some users and then tested by the 29 students as the users of the product. After that, a summative test was administered to them. The result of the study shows that: (1) the product namely Adaptive Mobile Learning fulfils the criteria and has been claimed as appropriate to be used as learning media according to the validation from the materials experts, media experts, and students who use the product with the average appropriateness score of 3.35 which belongs to the category of "very good"; and (2) the usefulness of the product is confirmed by the difference of the results of the last and early tests, that of after and before the use of the product of Adaptive Mobile Learning with raise the score of 33,80 after use the product, and that it supports the process of blended learning with the average appropriateness score of 3,42 which belongs to the category "very good".
\end{abstract}

Keywords: adaptive learning, mobile learning, blended learning 



\section{Pendahuluan}

Mata pelajaran Biologi di jenjang pendidikan SMA/MA termasuk ke dalam kelompok ilmu pengetahuan dan teknologi yang bertujuan untuk memperoleh kompetensi lebih lanjut serta membudayakan berpikir ilmiah secara kritis, kreatif dan mandiri (Mendiknas, 2006). Mata pelajaran Biologi bertujuan agar peserta didik memiliki kemampuan untuk; (1) membentuk sikap positif terhadap mata pelajaran Biologi dengan menyadari keteraturan dan keindahan alam serta mengagungkan kebesaran Tuhan Yang Maha Esa, (2) memupuk sikap ilmiah yaitu jujur, objektif, terbuka, ulet, kritis, dan dapat bekerjasama dengan orang lain. (3) mengembangkan pengalaman untuk dapat mengajukan dan menguji hipotesis melalui percobaan, serta mengkomunikasikan hasil percobaan secara lisan dan tertulis. (4) mengembangkan kemampuan berpikir analisis, induktif, dan deduktif dengan menggunakan konsep dan prinsip Biologi. (5) mengembangkan penguasaan konsep, dan prinsip Biologi, dan saling keterkaitananya dengan IPA lainnya serta mengembangkan pengetahuan, keterampilan, dan sikap percaya diri. (6) menerapkan konsep dan prinsip Biologi untuk menghasilkan karya teknologi sederhana yang berkaitan kebutuhan manusia. (7) meningkatkan kesadaran dan berperan serta dalam menjaga kelestarian lingkungan (Nunung, Syaiful, \& Teti, 2014, p. 4).

Fenomena di lapangan menunjukkan bahwa mata pelajaran Biologi sulit dipahami oleh peserta didik karena beberapa materinya bersifat abstrak. Di samping itu terdapat istilah-istilah asing yang juga sulit untuk dipahami. Proses pembelajaran yang masih sebatas menyampaikan informasi belum cukup untuk membantu peserta didik belajar Biologi secara utuh.

Penetrasi smartphone dan mobile device berbasis Android memiliki dampak positif dan negatif. Beberapa dampak positif yang timbul adalah akses informasi dan komunikasi yang lebih cepat, mudah dan efisien. Selain itu, proses mengirim doku- men, promosi di internet dan sosial media semakin pesat. Dampak positif lainnya membantu memudahkan berbagai pekerjaan manusia dalam berbagai bidang. Adapun dampak negatif yang ditimbulkannya seperti banyak waktu yang terbuang, misalnya terlalu lama di sosial media, melayani chating via instant messaging dan main games hingga lupa waktu. Hal itu didukung oleh fakta di lapangan, yang menunjukkan bahwa penggunaan smartphone yang dimiliki oleh responden yang lebih banyak digunakan untuk aktivitas di sosial media dibandingkan dengan kegiatan pembelajaran. Data menunjukkan 90,3\% peserta didik memiliki dan menggunakan aplikasi BBM, 93,5\% peserta didik menggunakan aplikasi Whatapps, 80,6\% memiliki akun Twitter, 77,4\% menggunakan akun Facebook (Surahman, 2015, p. 8).

Dalam sehari semalam 32,3\% responden memenggunakan perangkat smartphone selama 3-5 jam, sedangkan $25,8 \%$ rata-rata menggunakan smartphone lebih dari 7 jam. 22,6\% menggunakannya di bawah 3 jam, dan 19,4\% rata-rata menggunakannya antara 5-7 jam. Fakta lainnya dari lama waktu penggunaan smartphone tersebut diperoleh data bahwa $29 \%$ online di sosial media yang dimilikinya lebih dari 5 jam, sedangkan $25,8 \%$ rata-rata $1-5$ jam online di sosial media (Surahman, 2015, p. 7).

Data tersebut memberikan gambaran yang jelas bahwa kepemilikan mobile device berupa smartphone di kalangan pelajar perlu diberikan kontrol baik dari orang tua maupun, yang lebih penting, dari dirinya sendiri yang diberikan pemahaman bahwa penggunaan smartphone harus benar-benar dimanfaatkan untuk hal-hal yang bermanfaat bukan hanya sekedar sosial media yang kurang berkontribusi positif terhadap rencana masa depannya.

Lamanya seseorang online di sosial media berdampak pada beban pulsa untuk paket data yang digunakan dan instan messaging. Fakta menunjukkan bahwa $51,6 \%$ responden menyatakan menghabiskan pulsa antara 5-20 ribu perminggu atau 20-80 ribu dalam satu bulan. Dari data 
tersebut diperoleh fakta bahwa 87,1\% responden menyatakan membeli pulsa dari uang pemberian orang tua (Surahman, 2015, p. 9). Apabila hal tersebut tidak dikontrol dengan baik, maka akan terjadi beban pengeluaran tambahan bagi para orang tua untuk keperluan anak-anaknya yang belum tentu keperluan tersebut benar-benar dibutuhkan untuk kepentingan yang positif.

Diperlukan inovasi dalam pengembangan media pembelajaran untuk mendukung optimalisasi proses pembelajaran Biologi dan membantu peserta didik mencapai tujuan pembelajaran. Dalam kegiatan pembelajaran media memiliki peran yang penting yakni untuk menyampaikan materi pelajaran kepada pesera didik. Degeng (2013, p. 162) menjelaskan bahwa media pembelajaran adalah komponen strategi penyampaian yang dapat dimuati pesan yang akan disampaikan kepada si-belajar, apakah itu orang, alat, atau bahan.

Kemp dan Dayton (Daryanto, 2010, p. 6) menjabarkan media pembelajaran memiliki kontribusi di antaranya: penyampaian pesan pembelajaran dapat lebih terstandar, pembelajaran dapat lebih menarik, pembelajaran menjadi lebih interaktif dengan menerapkan teori belajar, waktu pelaksanaan pembelajaran dapat diperpendek, kualitas pembelajaran dapat ditingkatkan, proses pembelajaran dapat berlangsung kapanpun dan dimanapun diperlukan, sikap positif peserta didik terhadap materi pembelajaran serta proses pembelajaran dapat ditingkatkan, peran guru mengalami perubahan kearah yang positif.

Cobcroft et al. (Sugiyarto, 2014, p. 8) menyebutkan bahwa mobile learning sangat membutuhkan media yang menerapkan teknologi untuk menjalin komunikasi antara guru dan peserta didik. Lebih lanjut Cobcroft menyebutkan bahwa media yang digunakan dalam mobile learning harus dapat memenuhi kriteria: media tersebut dapat mendukung lifelong learning, media tersebut memperhitungkan mobilitas pengguna, media tersebut dapat digunakan secara pribadi dan pada aktivitas tertentu dengan didukung teknologi, media tersebut menerapkan pembelajaran yang berpusat pada peserta didik.

Media pembelajaran selain berfungsi sebagai pengantar pesan pembelajaran kepada peserta didik, juga dapat memudahkan proses peserta didik memahami materi yang diajarkan. Selain itu media pembelajaran dapat meningkatkan motivasi belajar peserta didik. Dengan demikian media pembelajaran yang baik dapat memudahkan peserta didik memahami materi pembelajaran dan meningkatkan hasil belajar peserta didik.

Inovasi media pembelajaran dewasa ini dituntut kreatif dan dapat menyesuaikan dengan perkembangan ilmu pengetahuan dan teknologi. Perkembangan teknologi perangkat bergerak (mobile device) yang pesat memberikan peluang dalam pengembangan media pembelajaran bergerak (mobile learning).

Mobile learning adalah pembelajaran yang dikemas melalui perangkat bergerak (mobile device). Mobile learning memudahkan para peserta didik untuk belajar kapan saja dan di mana saja. Strategi tersebut memudahkan para peserta didik untuk menguasai kompetensi materi secara utuh dalam waktu yang lebih cepat dari media pembelajaran yang lain (Rekkedal \& Dye, 2009, pp. 71-72; Economides, 2008, p. 6).

Pengembangan multimedia mobile learning yang baik dapat memenuhi prinsip personalized learning yakni mampu menyesuaikan dengan karakteristik peserta didik (Tortorella \& Graf, 2012, p. 671). Salah satu karakteristik peserta didik adalah keunikan antara satu dengan yang lainnya baik dari kemampuan awal, kecepatan menguasi materi, maupun gaya belajar. Multimedia mobile learning yang dapat menyesuaikan diri dengan perberadaan karateristik gaya belajar peserta didik dinamakan adapitve mobile learning.

Huang, Wang, \& Hsieh (2012, p. 340) menjelaskan bahwa untuk dapat memfasilitasi keragaman perangkat mobile yang tersedia perlu meningkatkan kenyamanan dan efisiensi belajar dalam ling- 
kungan pembelajaran bergerak. Selain itu diperlukan upaya untuk mengidentifikasi kapabilitas perangkat setiap individu, penyesuaian konten yang dapat menyediakan solusi atas keberagaman perangkat pengguna. Dengan demikian diperlukan sebuah mekanisme diagnosa pembelajaran untuk mengetahui pengetahuan awal peserta didik, gaya belajar setiap peserta didik.

Adaptive mobile learning adalah program multimedia pembelajaran yang menyajikan materi pembelajaran melalui perangkat bergerak (mobile device) dan memiliki kemampuan untuk menyesuaikan dengan karateristik gaya belajar pengguna (student learning styles). Kemampuan tersebut disebabkan adanya fitur khusus program multimedia berupa instumen untuk mengukur gaya belajar pengguna sebelum masuk pada room materi. Dengan demikian para pengguna dapat belajar sesuai dengan kecenderungan gaya belajar masing-masing.

Özyurt \& Özyurt $(2015$, p. 350) mengatakan bahwa belajar adalah proses yang sulit dan kompleks. Beberapa parameter yang harus diperhatikan pada karakteristik peserta didik di antaranya persepsi dan operasi pengetahuan pada diri peserta didik, keterampilan umum, potensi berkembangnya dan faktor lingkungan memainkan peran yang penting dalam prosesnya. Dalam proses pembelajaran pendidik harus mampu membaca karakter dominan para peserta didik. Dengan demikian program layanan belajar dapat dikemas sesuai dengan karakteristik yang paling dominan. Salah satu kateristik peserta didik yang perlu diperhatikan adalah perbedaan gaya belajarnya. Gaya belajar peserta didik memiliki perbedaan antara satu dengan yang lainnya (Surjono, 2011, p. 2350).

Perbedaan gaya belajar peserta didik dapat berhubungan dengan kecepatan peserta didik dalam mencerna dan menyerap informasi yang diperoleh. Duckett \& Tatarkowski (2005, p. 11) mendefisinikan gaya belajar adalah cara di mana seorang peserta didik dapat mempelajari sesuatu, lebih tepatnya berkaitan dengan cara dan pendekatan peserta didik dan pengalaman belajar serta dalam menggunakan informasi. Lebih jauh Duckett \& Tatarkowski (2005, p. 11) menjabarkan bahwa terdapat berbagai pandangan mengenai gaya belajar seseorang, apakah itu faktor genetik atau tergantung pada bagian otak yang paling mudah menerima dan bertanggungjawab dalam mengatur informasi yang telah dipelajarinya. Namun, ada kemungkinan bahwa gaya belajar merupakan hasil interaksi antara apa yang diwariskan secara genetik dengan pengalaman yang telah dipelajari.

Dalam beberapa penelitian diperoleh simpulan bahwa adaptive mobile learning terbukti efektif untuk membantu peserta didik belajar mencapai tujuan pembelajaran secara efektif dan efisien. Selain itu adaptive mobile learning memudahkan proses pembelajaran karena dapat dilakukan tanpa terikat waktu dan ruang. Pengguna dapat belajar kapan saja dan di mana saja sesuai kebutuhan dirinya untuk belajar.

Produk adaptive mobile learning yang dikembangkan bertujuan untuk menjadi salah satu alaternatif media pembelajaran peserta didik. Di samping itu diharapkan mampu mendukung proses pembelajaran campuran (blended learning). Proses blended learning adalah proses pembelajaran dengan mengombinasikan antara model pembelajaran konvensional dengan bantuan media pembelajaran berbasis teknologi informasi dan komunikasi. Adapun yang dimaksud media TIK dalam hal ini adalah produk adaptive mobile learning yang dikembangkan.

Micelle Pieri (Sugiyarto, 2014, p. 4) menjelaskan pembelajaran dengan menggunakan media mobile learning membuat pembelajaran peserta didik menjadi menarik dan menyenangkan. Proses belajar akan efektif apabila peserta didik berada dalam kondisi senang dan bahagia. Begitu juga sebaliknya, peserta didik akan merasa takut, cemas, was-was, merasa tidak nyaman yang dapat mengakibatkan hasil ku- 
rang optimal apabila proses belajar peserta didik terlalu dipaksakan (Susanto, 2009, pp. 19-20).

Newby (2000, p. 108) menyatakan ada sembilan hal untuk menilai kualitas multimedia pembelajaran: (1) melibatkan partisipasi peserta didik dengan penggunaan beberapa media yang digunakan, (2) memberikan kebebasan gaya belajar peserta didik, (3) melatih hampir semua domain pembelajaran (kognitif, afektif dan psikomotorik), (4) memberikan contoh yang realistis dengan tampilan video yang diberikan, (5) membangkitkan motivasi belajar peserta didik melalui penggunaan komposisi, warna, grafis, suara, musik, animasi, dan video yang tepat, (6) mebih interaktif dengan menggunakan tomboltombol yang tersedia dalam memberi respon peserta didik, (7) mengarah ke pembelajaran individu dengan memberikan kebebasan kepada peserta didik sesuai tingkat kemampuannya, (8) monsistensi dalam tampilan media, (9) dapat dikontrol sesuai dengan kecepatan berpikir peserta didik.

Berdasarkan beberapa pendapat di atas dapat disimpulkan bahwa kriteria evaluasi program multimedia adaptive mobile learning pembelajaran setidaknya harus memperhatikan beberapa hal sebagai berikut: (1) kesesuaian antara materi dengan kurikulum yang tertuang dalam silabus dan RPP, (2) kesesuaian materi adaptive mobile learning yang dikembangkan sesuai dengan analisis masalah dan kebutuhan lapangan, (3) kemampuan adaptive mobile learning yang dikembangkan dalam memberikan kebebasan kepada pengguna sesuai dengan gaya belajarnya, (4) kemampuan adaptive mobile learning yang dirancang sesuai dengan tingkat kemampuan pengguna, (5) kejelasan petunjuk program adaptive mobile learning bagi pengguna, (6) kemudahan navigasi progam adaptive mobile learning, (7) keserasian antara elemen adaptive mobile learning yang digunakan baik teks, gambar, audio, video maupun animasi, (8) kemampuan pengguna untuk mengontrol adaptive mobile learning yang digunakannya, (9) mengarah ke pembel- ajaran individu, (10) mampu melatih semua domain pembelajaran pengguna (kognitif, afektif dan psikomotorik), (12) Serasi dalam pemilihan warna elemen adaptive mobile learning, (13) pengemasan materi secara ringkas dan substantif, (14) Soal dan latihan uji kompetensi sesuai dengan materi yang dimunculkan dalam adaptive mobile learning.

Dalam rangka menghasilkan produk adaptive mobile learning yang baik diperlukan proses validasi. Penilaian kelayakan produk dilakukan oleh ahli materi dan ahli media serta calon pengguna. Produk adaptive mobile learning yang dikembangkan dinyatakan layak menurut ahli materi apabila telah memenuhi kriteria kelayakan yang terdiri dari 5 aspek kelayakan diantaranya aspek pembelajaran, aspek kelengkapan isi, aspek ketuntasan, ketepatan dan kebermaknaan, serta aspek ketercernaan dan kebahasaan. Adapun kriteria uji kelayakan produk adaptive mobile learning oleh ahli media meliputi aspek kemudahan pengoperasian, aspek kemudahan navigasi, aspek kemampuan adaptif terhadap gaya belajar pengguna, aspek kualitas tampilan, dan aspek kualitas ilustrasi.

Sementara itu kebermanfaatan program yang dikembangkan dan dinyatakan layak dapat diukur melalui uji respon pengguna. Selain itu dengan menggunakan angket soal uji kompetensi yang bertujuan untuk mengetahui perbedaan hasil belajar sebelum dan sesudah menggunakan produk adaptive mobile learning serta kemampuan produk mendukung proses blended learning.

Cisco System (Rusman, Kurniawan, \& Riyana, 2012, p. 244) mendefinisikan blended learning As combination of characteristic from both traditional learning and blended e-learning environment. It merges aspect of blended elearning such as webcommunication, etc; with traditional face to face learning. Blended learning sebagai kombinasi karakteristik pembelajaran tradisonal dan lingkungan pembelajaran elektronik atau blended e-learning. Menggabungkan aspek blended e-learning seperti pembelajaran ber- 
basis web, streaming video, komunikasi audio synkronus, dan asynkronus dengan pembelajaran tatap muka.

Kriteria kebermanfaatan produk adaptive mobile learning menurut pengguna di antaranya aspek kemudahan pengoperasian dan navigasi, aspek daya tarik produk, aspek daya dukung produk terhadap proses blended learning, aspek kemampuan adaptif terhadap perbedaan gaya belajar pengguna, serta aspek manfaat produk adaptive mobile learning.

Berdasarkan latar belakang tersebut, maka rumusan masalah dalam peneltiian ini yaitu: (1) bagaimana menghasilkan produk adaptive mobile learning pada mata pelajaran Biologi di SMA?, 2) bagaimana kebermanfaatan produk adaptive mobile learning pada mata pelajaran Biologi di SMA dalam meningkatkan hasil belajar peserta didik dan mendukung blended learning?

Berdasarkan rumusan tersebut, penelitian dan pengembangan ini bertujuan untuk: (1) menghasilkan produk adaptive mobile learning yang layak pada mata pelajaran Biologi di SMA; (2) mengetahui kebermanfaatan produk adaptive mobile learning yang dihasilkan dalam meningkatkan hasil belajar peserta didik dan mendukung blended learning.

\section{Metode Penelitian}

Penelitian ini mengunakan metode penelitian dan pengembangan atau disebut Research and Development (R \& D) Penelitian dan pengembangan ini bertujuan untuk menghasilkan produk adaptive mobile learning berupa media pembelajaran berbasis Android bagi peserta didik SMA/MA kelas XI IPA.

Model pengembangan yang digunakan oleh peneliti mengadopsi model pengembangan multimedia pembelajaran yang dikembangkan oleh Alessi \& Trollip (2001, p. 410). Secara umum memuat tiga proses utama yakni perencanaan (planning), perancangan (design), dan pengembangan (development).
Penelitian ini dilaksanakan selama 8 bulan dari bulan September 2015- April 2016 bertempat di Sekolah Menangah Atas (SMA) Negeri 1 Depok Kabupaten Sleman Daerah Istimewa Yogyakarta. Responden penelitian pengembangan ini adalah pesera didik kelas XI IPA 3 SMAN 1 Depok Sleman Yogyakarta tahun ajaran 2015/2016 semester 2. Responden keselurusan berjumlah 37 orang, dengan rincian: dua orang ahli media dan dua orang ahli materi pada proses uji alfa, 5 peserta didik pada uji beta 1 dan 29 peserta didik pada uji beta 2 .

Prosedur penelitian pengembangan ini di antaranya sebagai berikut: (1) perencanaan meliputi: mendefinisikan bidang/ ruang lingkup, mengidentifikasi karakteristik peserta didik, membuat dokumen perencanaan, menentukan dan mengumpulkan sumber-sumber, melakukan brainstorming; (2) perancangan meliputi: melakukan analisis konsep dan cakupan materi, menentukan komponen program, membuat flowchart dan storyboard, menentukan software-software yang akan digunakan; (3) Pengembangan meliputi: menyiapkan naskah materi, menggabungkan bagian-bagian media (teks, audio, video, animasi, gambar) dan memadukan berbagai bahan membuat program adaptive mobile learning secara utuh sampai tidak ditemukan bug dan error yang menandakan produk adaptive mobile learning siap dilakukan uji alfa, melakukan uji alfa untuk memvalidasi produk oleh dua ahli media, dua ahli materi, membuat revisi pertama, melakukan uji beta 1 kepada lima orang peserta didik calon pengguna produk, melakukan revisi, melakukan uji beta 2 dengan mengujikan produk A-Mol Bio pada kelompok kecil (satu kelas) untuk mengetahui tanggapan pengguna mengenai produk yang dikembangkan, membuat revisi akhir, melakukan uji summatif dengan mengadakan pretest dan posttest pada peserta uji beta, untuk membandingkan kebermanfaatan produk dalam mencapai tujuan pembelajaran yakni tercapainya target KKM mata pelajaran Biologi. 
Data dalam penelitian dan pengembangan ini adalah data kualitatif dan data kuantitatif. Data kualitatif diperoleh dari hasil analisis kebutuhan dan wawancara pada saat prasurvey. Data kualitatif diperoleh dari penilaian ahli media, ahli materi dan peserta didik melalui angket yang dianalisis secara deskriptif menggunakan skala 4. Selain itu data kuantitatif diperoleh dari hasil pretest dan postest hasil belajar peserta didik. Data-data tersebut dideskripsikan sebagai bahan pertimbangan untuk merevisi produk adaptive mobile learning yang dikembangkan. Selian itu, data kuantitatif dan kualitatif digunakan untuk mengukur kualitas kebermanfaatan produk yang dikembangkan agar dapat digunakan dalam proses pembelajaran.

Instrumen yang digunakan dalam penelitian dan pengembangan ini terdiri dari angket, wawancara, soal tes uji kompetensi dan dokumentasi. Angket ditujukan untuk peserta didik pada saat prasurvei, ahli materi, ahli media, dan peserta didik pengguna produk. Wawancara dilakukan pada saat prasurvei, soal tes uji kompetensi digunakan pada saat pretest dan posttest. Dan dokumentasi digunakan sejak prasurvei sampai pelaksanaan uji formatif. Sebelum digunakan, instrumen divalidasi oleh validator instrumen. Instrumen yang divalidasi meliputi angket untuk ahli media, angket untuk ahli materi, instrumen gaya belajar, dan angket untuk peserta didik. Sedangkan soal uji kompetensi divalidasi oleh ahli materi bersamaan dengan proses validasi materi.

Teknik pengumpulan data yang digunakan dalam penelitian ini menggunakan kuisioner (angket), observasi, wawancara dan soal uji kompetensi. Sedangkan instumen yang digunakan adalah angket, lembar observasi, pedoman wawancara dan soal pre test dan post tes. Data kualitatif berupa saran dan masukan dari ahli media, ahli materi serta peserta didik pada uji beta 1 . Semuanya dihimpun dan disimpulkan untuk memperbaiki kualitas produk yang dikembangkan. Sedangkan data kuantitatif berupa skor angket dari ahli media, ahli materi dan peserta didik yang diperoleh dari angket yang menggunakan skala likert yang dikonversikan ke dalam skala 4, yakni sangat layak, layak, tidak layak dan sangat tidak layak.

Langkah-langkah dalam analisis data kuantitatif meliputi: (1) mengumpulkan data mentah, 2) pemberian skor, (3) skor yang diperoleh kemudian dikonversikan menjadi nilai dalam skala 4 dengan menggunakan kriteria acuan yang dikembangkan oleh Mardapi (2008, p. 128).

Tabel 1. Kriteria Acuan Penskoran

\begin{tabular}{cccl}
\hline Nilai & Rumus & Rentang & \multicolumn{1}{c}{ Kategori } \\
\hline 4 & $X \geq \bar{X}+1 . S B_{X}$ & $4 \mathrm{X}>3,00$ & Sangat Layak \\
3 & $\bar{X}+1 . S B_{X}>X \geq \bar{X}$ & $2,50<\mathrm{X} \leq 3,00$ & Layak \\
2 & $\bar{X}>X \geq \bar{X}-1 . S B_{X}$ & $2,00<\mathrm{X} \leq 2,50$ & Tidak Layak \\
1 & $X<\bar{X}-1 . S B_{X}$ & $\mathrm{X} \leq 2,00$ & $\begin{array}{l}\text { Sangat Tidak } \\
\text { Layak }\end{array}$ \\
\hline
\end{tabular}

\section{Hasil Penelitian dan Pembahasan}

Hasil penelitian dan pengembangan ini adalah program multimedia pembelajaran adaptive mobile learning pada mata pelajaran Biologi SMA. Program yang dikembangkan berupa program aplikasi berbasis Android. Perbedaan program adaptive mobile learning dengan program mobile learning yang sudah banyak berkembang terletak pada fitur tes gaya belajar pengguna. Dengan demikian sebelum pengguna memasuki menu materi, terlebih dahulu di tes gaya belajar dominannya.

Instrumen tes gaya belajar mengadaptasi dari instrumen Visual, Auditorial dan Kinestetik (VAK) test yang dikembangkan oleh Chislett \& Chapman (2005, pp. 1-4). Jumlah soal tes sebanyak 25 soal.

Setelah produk selesai dikembangkan, kemudian divalidasi oleh ahli materi dan ahli media. Tujuan proses validasi ahli materi adalah untuk mengukur dan menilai derajat keabsahan materi yang dikembangkan, yakni materi sistem saraf pada manusia. Di samping itu untuk mengukur dan menilai aspek pembelajaran yang dikemas dalam produk Adaptive 
Mobile Learning (A-MoL) yang dikembangkan. Keduanya bertujuan untuk menghasilkan produk yang baik dan layak dari aspek materi dan pembelajaran.

Secara umum ada empat aspek yang divalidasi oleh ahli materi yakni aspek pembelajaran, aspek kebenaran isi, aspek ketuntasan, ketepatan dan kebermaknaan materi serta aspek ketercernaan dan kebahasaan materi yang disajikan dalam produk Adaptive Mobile Learning (A$M o L)$ yang dikembangkan.

Validasi media bertujuan untuk mengukur tingkat kelayakan media yang dikembangkan sebelum digunakan pada tahap pengembangan selanjutnya. Kedua ahli media diberikan instrumen untuk menilai kualitas media secara keseluruhan. Validasi media terdiri dari lima aspek. Pertama aspek kemudahan pengoperasian media, kedua kemudahan navigasi, ketiga kemampuan adaptif terhadap gaya belajar pengguna, keempat kualitas tampilan dan kelima kualitas ilustrasi.

Adapun hasil validasi dari kedua ahli materi sebagaimana Gambar 1.

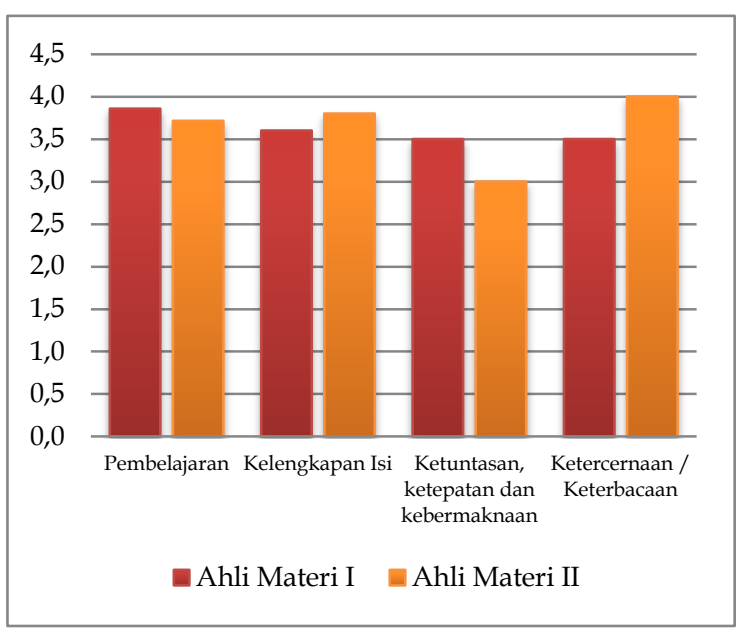

Gambar 1. Diagram Validasi Ahli Materi

Berdasarkan gambar diagram validasi ahli materi menunjukkan bahwa secara keseluruhan hasil validasi ahli materi masuk kategori sangat layak hal tersebut berdasarkan rata-rata skor dari hasil kedua validator materi menunjukkan angka 3,62. Skor tersebut berdasarkan hasil rata-rata skor validasi dari setiap aspek yakni aspek pembelajaran dengan rerata skor 3,79 dengan kategori sangat layak, pada aspek kelengkapan isi mencapai skor rata-rata 3,70 dengan kategori sangat layak, pada aspek ketuntasan, ketepatan dan kebermaknaan isi mencapai rata-rata skor 3,25 dengan kategori sangat layak, kemudian aspek ketercernaan dan kebahasaan mencapai rata-rata skor 3,75 dengan kategori sangat layak.

Selanjutnya hasil validasi ahli media sebagaimana Gambar 3.

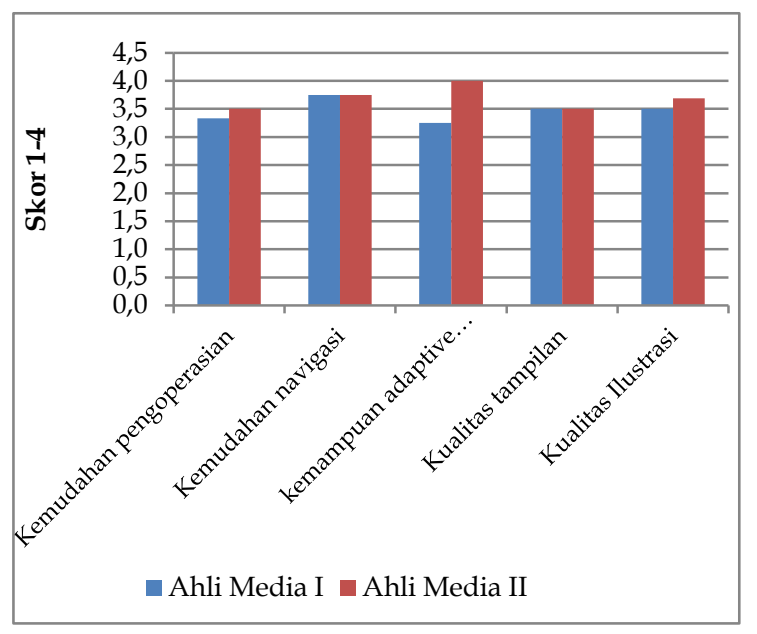

Gambar 2. Diagram Hasil Validasi Ahli Media

Gambar 2 tentang diagram validasi ahli media tersebut menunjukkan bahwa secara keseluruhan hasil validasi dari kedua ahli media diperoleh rerata skor 3,53 hal tersebut menunjukkan penilaian dari kedua ahli media masuk kategori sangat layak. Rerata skor tersebut dijabarkan dalam pencapaian rerata skor setiap aspek diantaranya aspek kemudahan pengoperasian yang terdiri dari enam item indikator yang mencapi rerata skor 3,50 yang berarti masuk kategori sangat layak. Aspek kemudahan navigasi program dari empat item indikator diperoleh rerata skor 3,75 yang berarti masuk kategori sangat layak. Aspek kemampuan adaptive terhadap gaya belajar yang terdiri dari empat item indikator diperoleh rerata skor 4 yang berarti masuk kategori sangat layak. Aspek kualitas tampilan yang terdiri dari enam item indikator, diperoleh rerata skor 3,50 
yang berarti masuk kategori sangat layak, dan aspek kualitas ilustrasi yang terdiri dari tujuh item indikator diperoleh rerata skor 3,43 yang berarti masuk kategori sangat layak.

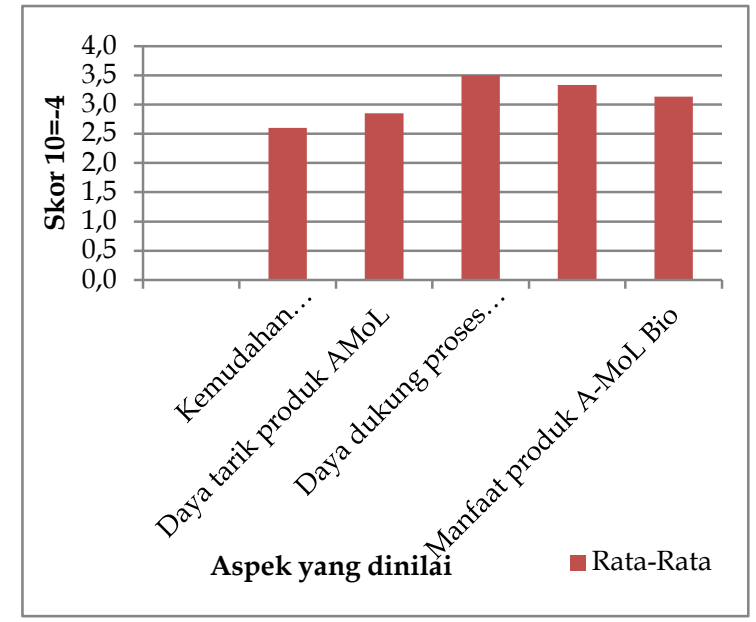

Gambar 3. Diagram Tanggapan Pengguna Produk

Berdasarkan Gambar 3 menunjukkan bahwa hasil uji beta 1 yakni sebanyak lima peserta didik pengguna uji coba produk Adaptive Mobile Learning (A-MoL) diperoleh rerata skor sebesar 2,99 yang menunjukkan kategori layak pada lima aspek yang diujicobakan. Secara rinci pada aspek kemudahan pengoperasian dan navigasi progam kelima pengguna uji coba memberikan penilaian baik/layak pada delapan item indikator dengan rerata skor sebesar 2,60. Sedangkan pasa aspek daya tarik progam kelima pengguna uji coba memberikan penilaian baik/layak pada empat item indikator dengan perolehan rerata skor sebesar 2,85.

Berdasarkan data dari hasil pengujian produk pada kelompok pengguna uji beta 2 diperoleh rerata total skor sebesar 3,26 yang masuk pada kategori sangat baik/layak. Secara rinci pada aspek kemudahan pengoperasian dan navigasi progam seluruh sampel uji beta memberikan penilaian sangat baik/sangat layak pada delapan item indikator dengan rerata skor sebesar 3,15. Sedangkan pasa aspek daya tarik program seluruh sampel uji beta 2 memberikan penilaian sangat baik/sangat layak pada empat item indikator dengan perolehan rerata skor sebesar 3,20.

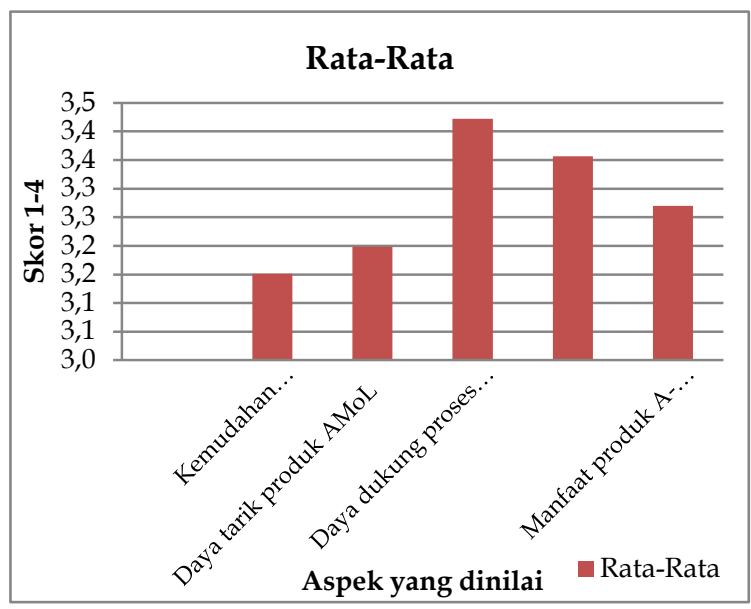

Gambar 4. Diagram Tanggal Pengguna

Uji Beta 2

Uji kompetensi kognitif terhadap peserta didik kelas XI IPA 3 SMAN 1 Depok Sleman Daerah Istimewa Yogyakarta sebagai pengguna program Adaptive Mobile Learning (AMoL) dilakukan melalui pretest dan posttest. Data pretest dan posttest kemudian dibandingkan untuk mengetahui signifikansi peningkatan hasil belajar antara pretest dan posttest sebelum dan sesudah menggunakan program yang dikembangkan. Adapun data tabel perbandingan hasil uji kompetensi kognitif dapat dilihat pada Tabel 2.

Tabel 2. Perbandingan Data Uji

Kompetensi Kognitif Pretest dan Postest.

\begin{tabular}{llcc}
\hline No & Variabel & Pretest & Posttest \\
\hline 1 & Nilai Terendah & 15 & 75 \\
2 & Nilai Tertinggi & 75 & 100 \\
3 & Rata-Rata & 53,93 & 87,69 \\
& Selisih & \multicolumn{2}{c}{33,8} \\
\hline
\end{tabular}

Secara visual tabel hasil penilaian uji kompetensi pada tahap uji beta 2 kepada peserta didik pengguna program Adaptive Mobile Learning (AMoL) dapat dilihat pada Gambar 5.

Berdasarkan analisis data pretest dan posttest pada Gambar 5 dapat diketahui bahwa terjadi peningkatan skor hasil 
uji kompetensi antara sebelum dengan sesudah menggunakan program Adaptive Mobile Learning (AMoL) yang dikembangkan. Dengan demikian indikator ketuntasan pembelajaran tercapai, hal tersebut didasarkan pada data yang menunjukkan semua peserta didik dapat mencapai skor minimal 75. Data rata-rata masing-masing kelompok gaya belajar secara visual data pada Tabel 2 dapat dilihat para Gambar 6 .

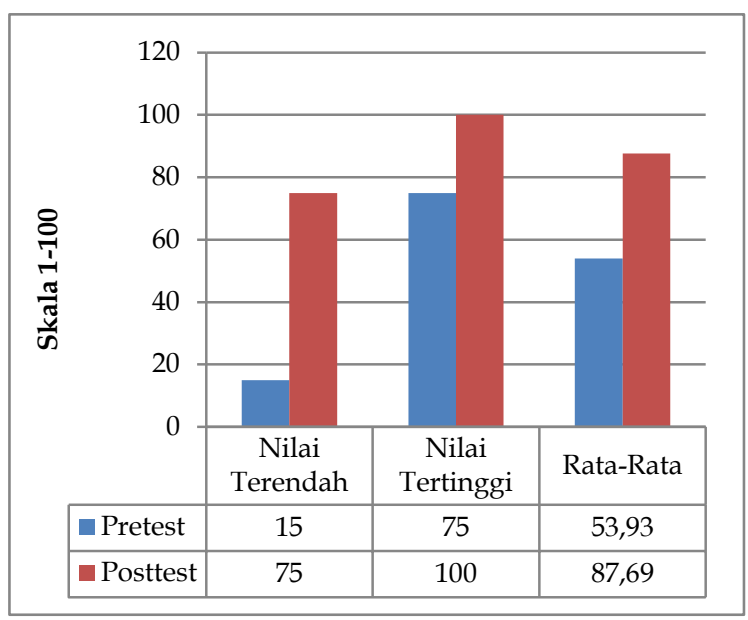

Gambar 5. Diagram Perbandingan Data Pretest dan Posttest

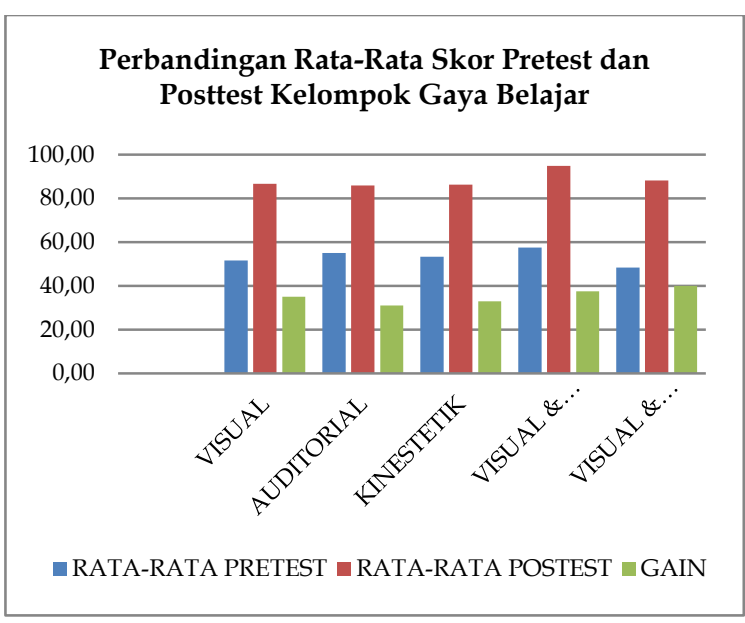

Gambar 6. Diagram Perbadingan RataRata Skor Pretest dan Posttest setiap Kelompok Gaya Belajar

Berdasarkan Gambar 6 tersebut terlihat perbandingan rata-rata skor pretest dan posttest masing-masing kelompok gaya belajar para pengguna produk Adaptive Mobile Learning (A-MoL). Secara umum rata-rata posttest mengalami peningkatan di atas $30 \%$. Namun besaran persentase peningkatannya berbeda pada setiap gaya belajar. Peningkatan rata-rata skor posttest pada gaya belajar visual sebesar $35 \%$. Adapun peningkatan rata-rata skor posttest pada gaya belajar auditorial sebesar $31 \%$. Peningkatan rata-rata skor posttest pada gaya belajar kinestetik sebesar 33\%. Sementara peningkatan rata-rata skor posttest pada gaya belajar visual auditorial sebesar 37,50 dan jumlah peningkatan rata-rata skor posttest yang paling besar terjadi pada kelompok gaya belajar visual kinestetik sebesar $40 \%$.

\section{Simpulan dan Saran}

Berdasarkan hasil penelitian dan pengembangan, dapat disimpulkan bahwa produk Adaptive Mobile Learning (A-MoL) pada mata pelajaran Biologi SMA dinilai layak digunakan sebagai media pembelajaran ditinjau dari materi dan media dan respon pengguna pada uji beta 1 dan 2 . Kelayakan tersebut dapat dilihat dari rerata skor penilaian ahli materi sebesar 3,62 dengan kategori sangat layak, rerata skor ahli media sebesar 3,53 dengan kategori sangat layak, rerata skor uji beta 1 sebesar 2,99 dengan kategori layak dan rerata skor uji beta 2 sebesar 3,29 dengan kategori sangat layak. Produk Adaptive Mobile Learning ( $A-M o L)$ yang dikembangkan dinilai bermanfaat dibuktikan dengan peningkatan hasil belajar sebesar 33,80. Nilai ratarata pretest 53,93 meningkat waktu postest menjadi 87,69 dengan persentasi ketuntasan pencapain KKM sebesar $100 \%$. Di samping itu berdasarkan penilaian ahli dan peserta didik pengguna, produk yang dikembangkan dapat mendukung proses blended learning dengan rerata skor 3,42 dengan kategori sangat layak/mendukung. Saran

Program Aplikasi Adaptive Mobile Learning $(A-M o L)$ ini perlu diimplementasikan lebih lanjut pada cakupan yang lebih luas. Pendidik/guru baik pada sekolah formal maupun nonformal diharapkan mampu memanfaatkan program Adaptive 
Mobile Learning (A-MoL) untuk memfasilitasi alternatif media pembelajaran peserta didik. Materi yang disajikan sebaiknya dikembangkan juga untuk mata pelajaran yang lainnya terutama yang mendukung dikembangkan melalui pendekatan mobile learning.

Selian itu perlu pengembangan Adaptive Mobile Learning (A- MoL) yang dapat memfasilitasi perbedaan karakteristik gaya belajar selain gaya belajar visual, auditorial dan kinetetik misalnya gaya belajar global, analitik, maupun gaya belajar read-write. Pengembangan Adaptive Mobile Learning (A-MoL) yang dapat memfasilitasi sajian materi sesuai dengan karakteristik peserta didik lainnya seperti tingkat pengetahuan awal, asal daerah dan keepatan belajar para peserta didik.

\section{Daftar Pustaka}

Alessi, S. M., \& Trollip, S. P. (2001). Multimedia for learning: methods and development (3rd ed.). Boston: Allyn and Bacon.

Chislett, V., \& Chapman, A. (2005). VAK test. Retrieved from http://www.businessballs.com/freep dfmaterials/vak_learning_styles_ques tionnaire.pdf

Daryanto. (2010). Media pembelajaran peranannya sangat penting dalam mencapai tujuan pembelajaran. Yogyakarta: Gava Media.

Degeng. (2013). Ilmu pembelajaran klasifikasi variabel untuk pengembangan teori dan penelitian. Bandung: Aras Media.

Duckett, I., \& Tatarkowski, M. (2005). Practical strategies for learning and teaching on vocational programmes. United Kingdom: Learning and Skills Development Agency.

Economides, A. A. (2008). Context-aware mobile learning. The Open Knowlege Society. A Computer Science and Information Systems Manifesto, 213-220.

Huang, H.-C., Wang, T.-Y., \& Hsieh, F.-M.
(2012). Constructing an Adaptive Mobile Learning System for the Support of Personalized Learning and Device Adaptation. Procedia - Social and Behavioral Sciences, 64, 332-341. https:// doi.org/10.1016/j.sbspro.2012 .11 .040

Mardapi, D. (2008). Teknik penyusunan instrumen tes dan nontes. Yogyakarta: Mitra Cendikia Press.

Mendiknas. Peraturan menteri pendidikan nasional nomor 22 tahun 2006 standar isi untuk satuan pendidikan dasar dan menengah (2006). Republik Indonesia.

Newby, T. (2000). Instructional technology for teaching and learning. New Jersey: Merrill an Imprint of Prentice-Hall, Inc.

Nunung, N., Syaiful, A., \& Teti, S. (2014). Buku guru biologi untuk SMA/MA kelas XI. Bandung: Yrama Widya.

Özyurt, Ö., \& Özyurt, H. (2015). Learning style based individualized adaptive elearning environments: Content analysis of the articles published from 2005 to 2014. Computers in Human Behavior, 52, 349-358. https:// doi.org/10.1016/j.chb.2015.06 .020

Rekkedal, T., \& Dye, A. (2009). Mobile distance learning with pdas: development and testing of pedagogical and system solution supporting mobile distance learners. Norwegia: AU Press.

Rusman, Kurniawan, D., \& Riyana, C. (2012). Pembelajaran berbasis teknologi informasi dan komunikasi: mengembangkan profesionalisme guru. Jakarta: Rajawali Pers.

Sugiyarto. (2014). Pengembangan media mobile learning "Chem Edu" berbasis android sebagai suplemen materi kimia berdasarkan kurikulum 2013 untuk meningkatkan academic performance peserta didik SMA/MA. UNY: Tidak Diterbitkan. 
Surahman, E. (2015). Laporan observasi kepemilikan dan pemanfaatan perangkat telekomunikasi siswa SMAN 1 Depok Sleman Yogyakarta. Yogyakarta: tidak diterbitkan.

Surjono, H. D. (2011). The design of adaptive e-learning system based on student's learning styles. International Journal of Computer Science Information and Education Technologies (IJCSIT), 2(5), 2350-2353. Retrieved from http://ijcsit.com/docs/Volume 2/vol2issue5/ijcsit20110205108.pdf
Susanto, E. (2009). 60 games untuk mengajar. Yogyakarta: Lukita.

Tortorella, R. A. W., \& Graf, S. (2012). Personalized mobile learning via an adaptive engine. In 2012 12th IEEE International Conference on Advanced Learning Technologies (p. 671). Retrieved from http://sgraf.athabascau.ca/publicatio ns/tortorella_graf_DULPSPeL12.pdf 